Henryk Mizerek

https://doi.org/10.26881/pwe.2020.51.06

ORCID: 0000-0001-8674-2205

Uniwersytet Warmińsko-Mazurski w Olsztynie

mizerek@uwm.edu.pl

\title{
Ewaluacje konstruktywistyczne. Implikacje dla wczesnej edukacji
}

\section{Summary \\ Constructivist evaluation. Implications for early education}

The aim of this paper is to analyze the possibilities of using evaluation models - developed within the constructivist paradigm - in early education. The author's field of interest included responsive evaluation, dialogic evaluation, deliberative democratic evaluation, participatory evaluation, empowerment evaluation and stakeholder-based evaluation. Responsive and dialogical evaluation have been found to be particularly useful in early education. The scope of in-depth analyzes is aimed to present the specificity of responsive dialogical evaluations compared to other constructivist models and their distinctiveness from neoliberal evaluations and those subordinated to the gold standard ideology. The content of the second part of the paper is devoted to analyze the problems of designing, planning and conducting programs implemented in early education.

Keywords: constructivist evaluation, responsive evaluation, dialogic evaluation, evaluation models in early education

Słowa kluczowe: ewaluacje konstruktywistyczne, ewaluacja responsywna, ewaluacja dialogiczna, modele ewaluacji we wczesnej edukacji

\section{Wprowadzenie}

Wielu przedstawicieli teorii i praktyki edukacyjnej zadaje sobie pytanie: Jakiej ewaluacji potrzebujemy w szkole? Są silne podstawy do twierdzenia, że niekoniecznie takiej, z którą mamy współcześnie do czynienia w praktyce (Mizerek 2018). Upowszechniane współcześnie nurty, powstałe w ramach ewaluacji neoliberalnych oraz podporządkowanych ideologii ,złotego standardu” (Vedung 2010), są mało użyteczne. Służą one przede wszystkim przedstawicielom administracji edukacji różnych szczebli. Jak trafnie zauważa Bolesław Niemierko, komentując sposób istnienia ewaluacji w Polsce: „można ją uznać za planetę krążącą wokół nauczycielsko-kierowniczego słońca, oświetlaną jego blaskiem, wrażliwą na plamy" (2013: 12). Zadziwiające jest, dlaczego neoliberalizm, mimo jego krytyki oraz silnych argumentów wskazujących jego bezużyteczność (por. Potulicka, Rutkowiak 2010; Rutkowiak 2012; Klus-Stańska 2013; Potulicka 2014), jest nadal atrakcyjny dla władz oświatowych oraz wielu praktyków. Dzieje się tak mimo pełnej świadomości, 
że mamy do czynienia z promowaniem ewaluacji w postaci, którą w literaturze przedmiotu określa się mianem quasi-ewaluacji lub pseudoewaluacji (Stufflebeam 2001).

W tej sytuacji ważne staje szersze uobecnienie w dyskursie akademickim takich modeli ewaluacji, które są wyczulone na dobro i rozwój dziecka oraz rozumieją „duszę szkoły”. Przykładem takiego modelu są nurty w ewaluacji budowanej na założeniach paradygmatu konstruktywistycznego. Można je nazwać ewaluacjami konstruktywistycznymi (Mertens 2010).

Ewaluacje konstruktywistyczne cieszą się zainteresowaniem również w Polsce. Wśród przedstawicieli ewaluacji edukacyjnej jest to nurt wiodący. Kwestie teorii i metodologii ewaluacji konstruktywistycznych były podejmowane m.in. w pracach Leszka Korporowicza (2011, 2013), Henryka Mizerka (2017a, b), Sylwii Jaskuły (2018), Justyny Nowotniak (2017, 2019), Grażyny Szyling (2013), Marii Groewald (2013). Powstało również wiele publikacji poświęconych metodom zbierania i analizy danych jakościowych. Ich przykładem są opracowania Justyny Nowotniak $(2012,2013)$ poświęcone fotoewaluacji, analizy Sławomira Krzychały i Beaty Zamorskiej (2008) na temat wykorzystania metody dokumentarnej w ewaluacji codzienności szkolnej, publikacje Moniki Maciejewskiej i Adriany Matuszewskiej (2013) opisujące wykorzystanie zogniskowanych wywiadów grupowych w ewaluacji. Niestety teksty te są znane i dyskutowane raczej w wąskim gronie akademickich pedagogów zainteresowanych ewaluacją edukacyjną.

W niniejszym opracowaniu postawiłem sobie dwa zadania. Pierwszym z nich jest analiza poszczególnych nurtów ewaluacji konstruktywistycznych z perspektywy ontologicznych, epistemologicznych, metodologicznych oraz etycznych założeń paradygmatu, z którego się wywodzą. Drugim - próba wskazania na możliwości wykorzystania ewaluacji responsywnej oraz dialogicznej we wczesnej edukacji. Porządek treści artykułu wyznaczają następujące pytania:

- Na czym polega specyfika poszczególnych koncepcji ewaluacji konstruktywistycznych na tle innych nurtów i podejść w teorii ewaluacji?

- Jakie są potencjalne zastosowania ewaluacji konstruktywistycznych we wczesnej edukacji?

- Jakiego rodzaju założenia metodologiczne należy przyjąć w trakcie projektowania i prowadzenia ewaluacji responsywnej oraz dialogicznej?

\section{Istota i nurty ewaluacji konstruktywistycznych}

Ewaluacje responsywna oraz dialogiczna stanowią najbardziej reprezentatywne przykłady ewaluacji konstruktywistycznych lub inspirowanych założeniami konstruktywizmu. Ich lista jest znacznie dłuższa. Jako przykłady mogą służyć następujące koncepcje:

- deliberatywna ewaluacja demokratyczna (House, Howe 2000; Howe, Ashcraft 2005);

- ewaluacja partycypacyjna (Cousins, Earl 1992; Tapella, Rodríguez-Bilella 2014); 
- ewaluacja upełnomocniająca (Fettermann, Wandersman 2007);

- ewaluacja zogniskowana na potrzeby podmiotów sceny edukacyjnej (stakeholders-based evaluation) (Mehrizi i in. 2009).

Chcąc zrozumieć specyfikę ewaluacji konstruktywistycznych, warto przyjrzeć się poszczególnym jej modelom z punktu widzenia przyjmowanych założeń: ontologicznych, epistemologicznych, metodologicznych oraz etycznych. Pionierem ewaluacji konstruktywistycznych jest Robert Stake. Opracowany przez niego - we wczesnych latach 70. ubiegłego stulecia - model ewaluacji responsywnej (Stake 2003) stanowił swoisty przełom $\mathrm{w}$ dotychczasowym sposobie rozumienia ewaluacji jako instrumentu umożliwiającego wyrokowanie o „obiektywnej” wartości czy jakości badanych obiektów. Ewaluacja responsywna, respektując ontologię konstruktywizmu, zakłada, że istnieje wiele rzeczywistości, w tym także aksjologicznych. Każdy z podmiotów zaangażowanych w realizację jakiegoś projektu czy programu ma własne kryteria wartościowania jego rezultatów, przebiegu, treści czy metod. Stąd w ewaluacji responsywnej akcent kładzie się na opis osobistych doświadczeń badanych. Drugoplanowe znaczenie mają tutaj założenia i cele programu - ważniejsze jest dotarcie do subiektywnych, osobistych doświadczeń osób związanych z jego realizacją. Istotę ewaluacji responsywnej dobrze oddają słowa Stake'a: „Jest to podejście, które docenia znaczenie osobistego doświadczenia. Opisuje ono sposób, w jaki w życiu codziennym ludzie postrzegają jakość i wartość. Bardziej, niż w innych, formalnych podejściach do ewaluacji zwraca się tu uwagę na to, co dzieje się w trakcie realizacji programu, na jego unikatowość i zróżnicowanie kulturowe jego uczestników. Owo wyczulenie jest obecne na każdym etapie procesu badawczego; w każdej jego części oraz w raporcie są zawarte co najmniej ślady doświadczania dobra i zła" (Stake, Abma 2005: 378).

Ewaluacja responsywna ma na celu nie tylko dostarczanie informacji, lecz - przede wszystkim - tworzenie wiedzy. Warto zadać pytanie: jaki jest to rodzaj wiedzy? Z epistemologicznego punktu widzenia ${ }^{1}$ jest to wiedza najbliższa phronesis - taka, która umożliwia mądre, refleksyjne działanie. Podkreślanie etycznego wymiaru działania powoduje, że mamy tutaj do czynienia nie tylko $\mathrm{z}$ wiedzą o środkach i metodach osiągania założonych (często narzuconych) celów, ale przede wszystkim z wiedzą na temat etycznych skutków działań oraz wartości samych celów.

Zasługą Stake'a jest również opracowanie oryginalnej strategii badawczej, która umożliwia osiągnięcie celów ewaluacji responsywnej. Jest nią studium przypadku (case $s t u d y)$. W ujęciu tego autora studium przypadku jest podejściem skierowanym na odkrycie wyjątkowości i niepowtarzalności oraz złożoności pojedynczego przypadku. Warto podkreślić, że studium przypadku nie można potraktować jedynie jako metody zbierania danych. Jest to bardzo złożona i niełatwa w realizacji strategia badawcza, w której konieczne jest określenie rodzaju przypadku, zdefiniowanie jego granic oraz pamięć o tym, że jest to

1 W tradycyjnym rozumieniu termin ,wiedza" ma cztery znaczenia: 1) episteme; 2) techne; 3) phronesis; 4) metiers. 
przede wszystkim studium swoistości (singularity) badanych zjawisk (Stake 1995; Konecki 2000; Simons 2009; Mizerek 2017c).

Kolejnym modelem ewaluacji konstruktywistycznej są ewaluacje dialogiczne zaprezentowane w pracy Egona Guby i Yvonny Lincoln pt. Fourth Generation Evaluation (1989). Jest to zapewne najbardziej wpływowy, rozwijany również w Polsce (por. Grzesiak 2008; Korporowicz 2011, 2013; Nowotniak 2017, 2019; Mizerek 2017b, 2018; Jaskuła 2018), nurt w badaniach ewaluacyjnych inspirowanych konstruktywizmem. W tym modelu, nieco inaczej niż w wypadku ewaluacji responsywnej, rozłożone zostały akcenty na kwestie odnoszące się do celów ewaluacji, sposobów jej prowadzenia oraz komunikowania wyników.

W tym miejscu warto zwrócić uwagę na dwie kwestie. Pierwszą z nich jest rozumienie centralnej kategorii, jaką jest dialog. Na tym przykładzie niczym w soczewce widać sposób, w jaki założenia paradygmatyczne konstruktywizmu przekładają się na teorię i praktykę ewaluacji. Guba i Lincoln odrzucają instrumentalne traktowanie dialogu lub używając określenia Roberta Kwaśnicy (2014) - rozumienie go „w porządku czynu”. Sięgają po hermeneutykę, definiując dialog „w porządku rozumienia”.

Dialog w porządku rozumienia w swoisty sposób traktuje kwestie sposobu pojmowania wiedzy, prawdy i różnicy (por. Hall i in. 2012). Wiedza jest tutaj pojmowana szeroko i ontologicznie. Prawda nie jest rozważana pragmatycznie (jako pewność sądu mierzona skutecznością działania), lecz hermeneutycznie - staje się ujawniającą się w naszym doświadczeniu ,istotą wszystkiego, co wspólnie z nami bytuje”. Celem dialogu w porządku rozumienia jest pielęgnowanie różnic. Różnic nie odbiera się tutaj jako okoliczności negatywnej lub czegoś, co blokuje wspólne działanie.

Tak rozumiany dialog tworzy także możliwości przekraczanie granic. Pozwala na zrozumienie, że obok „naszego świata” istnieje także inny świat - subiektywna, społecznie i aktywnie konstruowana rzeczywistość innych ludzi i ich kultur. Dzięki temu otwieramy się na inne prawdy oraz na prawdę dotąd niedostępną. W dialogu zajmujemy się różnicami nie po to, by się od nich uwolnić, ale po to, by dzięki różnicom uczyć się prawdy. Uczestniczenie $\mathrm{w}$ dialogu pojmowanym $\mathrm{w}$ taki sposób umożliwia wejście „w dynamiczne relacje między wszystkimi biorącymi w nim udział osobami”. Dialog jest wówczas sytuacją, w której „krzyżują się jednostkowe perspektywy, współprzenikają (ale nie rozmywają) osobiste sensy i wypracowywane są nowe sposoby rozumienia świata i siebie samych" (Gołębniak, Zamorska 2014: 69).

Naszkicowane rozumienie dialogu pozwala zrozumieć cele i zadania ewaluacji dialogicznej. Jest nimi animacja dialogu podmiotów (stakeholders) uczestniczących w poddanych ewaluacji programach. Przedmiotem dialogu - jak pisałem wcześniej - są osobiste doświadczenia zgromadzone przez twórców programu, jego realizatorów, uczestników (beneficjentów) oraz szerszą publiczność. Zadanie ewaluatora to nie tylko zaprojektowa-

2 Podstawowym celem dialogu „w porządku czynu” jest uzgodnienie, co należy lub można uczynić w imię wspólnego dobra. Jest on tożsamy z dyskusją (por. Kwaśnica 2014). 
nie, przeprowadzenie oraz zakomunikowanie wyników, lecz przede wszystkim animacja i facylitacja dialogu.

Prowadzenie ewaluacji dialogicznej wymaga respektowania surowych rygorów etycznych. Guba i Lincoln (1989) zaproponowali zestaw kryteriów kodyfikujących relacje między prowadzącym badanie a jego uczestnikami. Fundamentem tego modelu jest para wartości, którą tworzą wiarygodność (trustworthiness) i autentyczność (authenticity).

Aktualizacja tych wartości w praktyce badawczej wymaga zachowania równowagi między czterema rodzajami autentyczności: ontologiczną (nakazującą budzenie świadomości uczestników badania, że konstruują rzeczywistość społeczną), edukacyjną (zobowiązującą badacza do dostarczania wiedzy o tym, jak wszyscy aktorzy sceny edukacyjnej, tj. stakeholders, doświadczają rzeczywistości), katalityczną (sprowadza się ona do zachęcania uczestników badania do podejmowania działań na rzecz własnego dobra) oraz taktyczną (nakazującą uczenie uczestników badania, jak działać na rzecz własnego dobra). Lista opisanych kryteriów została uzupełniona przez Lincoln (2009) o dodatkowe wartości: refleksywność (reflexivity), porozumienie (rapport) i wzajemność (reciprocity).

Szczególne znaczenie ma - w moim przekonaniu - refleksywność. Odnosi się ona nie tylko do standardów etycznych, lecz także jest niezbędną kompetencją metodologiczną w badaniach jakościowych. W wypadku ewaluacji respektowanie refleksywności zapewnia zachowanie naukowego statusu, wiarygodności oraz przydatności wiedzy generowanej przez te badania. Dzieje się tak, ponieważ refleksywność:

- pozwala na uświadomienie sobie wpływu cech ewaluatora na sposób projektowania, prowadzenia oraz komunikowania wyników badania;

- ujawnia nieświadome motywy i ukryte założenia realizowanych projektów;

- otwiera pole do namysłu nad poprawnością metodologiczną procesu badawczego oraz statusem jego wyników;

- promuje szczerość w ujawnianiu dylematów metodologicznych i etycznych, które pojawiły się trakcie badań.

Ewaluacje responsywna oraz dialogiczna - jak już wspominałem - stanowią najbardziej reprezentatywne przykłady ewaluacji konstruktywistycznych. Do tej grupy należą także ewaluacje: deliberatywna ewaluacja demokratyczna, partycypacyjna, upełnomocniająca oraz ewaluacja zogniskowana na potrzeby podmiotów sceny edukacyjnej. Każdy z tych nurtów, akceptując główne założenia paradygmatu konstruktywistycznego w nauce, jednocześnie wnosi nowe wątki w sposobie definiowania celów ewaluacji, roli ewaluatora oraz centralnych kategorii każdej z tych koncepcji.

Nowe wątki do rozumienia istoty i roli dialogu wniosła koncepcja deliberatywnej ewaluacji demokratycznej. Jej filarami są trzy wartości: inkluzja, dialog i deliberacja. Dialog jest tu pojmowany szerzej niż w „klasycznej” koncepcji Guby i Lincoln. Został on poszerzony o kategorię określoną jako „dialog krytyczny” (House, Howe 2000: 105), który poprzedza deliberację. Deliberacja jest niezbędna ze względu na charakter badań ewaluacyjnych, które z natury rzeczy są uwikłane w konflikty wartości oraz relacje władzy. 
Ewaluacje partycypacyjna, zorientowana na podmioty sceny edukacyjnej oraz upełnomocniająca to kolejne przykłady ewaluacji inspirowanych konstruktywizmem, w których dialog jest niezmiernie ważny, choć wykorzystuje się go w różny sposób i do nieco innych celów. Podkreśla się również znaczenie podmiotów zainteresowanych prowadzeniem ewaluacji (stakeholders).

Ewaluacje demokratyczne można podzielić na dwie grupy - prowadzone przez ludzi oraz dla ludzi. Ewaluacje prowadzone przez ludzi są rozwojowe (por. Chelimsky 1997). Ich zadania to wspomaganie procesów uczenia się, upełnomocnienie podmiotów sceny edukacyjnej oraz tworzenie poczucia sprawstwa w procesie wdrażania zmian. Do aktywnego udziału w badaniu i dialogu zaprasza się głównie tych, którzy realizują program (np. nauczycieli), i tych, którzy są jego bezpośrednimi (np. uczniów) lub pośrednimi (rodzice, środowisko lokalne, władze) adresatami. Zmienia się radykalnie również rola ewaluatora - nie jest on jedynie „wynajętym ekspertem”, ale staje się również „adwokatem” każdej z tych grup. Do jego powinności należy również facylitacja dialogu i zbiorowej, krytycznej refleksji oraz deliberacji.

Ewaluacje drugiego typu, prowadzone z ludźmi, mają na celu umożliwienie zaangażowanym w nie podmiotom (nie tylko prowadzącym badanie) zdobycie wiedzy pozwalającej na mądre działanie. Są to ewaluacje poznawcze (por. Chelimsky 1997), które podejmuje się w poczuciu odpowiedzialności za dobro wspólne. Włącza się w nie możliwie najszersze grono podmiotów. Ewaluator występuje w roli inicjatora publicznej debaty i dialogu. Postrzega on siebie także jako obywatela, zatroskanego istniejącym stanem rzeczy.

Zaprezentowane uwagi dają podstawę do podjęcia próby określenia specyficznych cech ewaluacji konstruktywistycznej. Niezależnie od różnic, które można dostrzec w każdej z jej nurtów, łączy je respektowanie ontologii, epistemologii, metodologii oraz aksjologii konstruktywistycznego paradygmatu w nauce.

Ewaluacje konstruktywistyczne są tą odmianą ewaluacji programów, która akcentuje cele poznawcze i rozwojowe. Zrywa się tutaj z tradycją nakazującą sprowadzanie ewaluacji do wydawania ostatecznych, niepodważalnych sądów na temat „obiektywnej” wartości rezultatów badanego programu. Zadaniem ewaluacji nie jest wartościowanie, badanie to nie jest też prowadzone $\mathrm{z}$ intencją dokonania oceny. W centrum uwagi ewaluacji nadal pozostaje badanie wartości, ale w sposób, jaki wyznaczają założenia konstruktywizmu (Mertens 2010: 18; Hall i in. 2012).

Ewaluacje konstruktywistyczne mają za zadanie tworzenie wiedzy idiograficznej odsłaniającej specyfikę oraz unikatowość doświadczeń oraz świat wartości wszystkich podmiotów (stakeholders) uczestniczących w realizacji programu. W odróżnieniu od badań jakościowych, prowadzonych w ramach paradygmatu konstruktywistycznego, ewaluacja ma znacznie szersze zadania. W procesie tworzenia wiedzy aktywnie uczestniczy wiele podmiotów. Badanie uwzględnia potrzeby i wartości każdego z nich (tak jak to się dzieje w ewaluacji responsywnej). Co więcej - badanie nie kończy się raportem. Jest to dopiero początek ewaluacji dialogicznej czy demokratycznej. Jej istotą i sensem jest facylitacja dialogu pojmowanego hermeneutycznie - „w porządku rozumienia”, a nie jedynie „w po- 
rządku czynu". Dialog, krytyczna refleksja i deliberacja nie są tutaj jednak celem samym w sobie. Stają instrumentem w dziele zmiany człowieka i jego społecznego świata. Stąd zadania ewaluatora nie ograniczają się jedynie do roli badacza - jest on jednocześnie edukatorem oraz aktywnym obywatelem.

Cechą wyróżniającą ewaluacje konstruktywistyczne jest również unikanie ujawniania przez badacza własnych ocen i wartości. Stąd raport z badań nie może zawierać rekomendacji. Treści raportu mają jedynie ujawniać zróżnicowane sposoby doświadczania zdarzeń przez ludzi. We wnioskach unika się generalizacji oraz uporczywego poszukiwania przyczyn zaobserwowanych stanów rzeczy. W ewaluacjach tego typu sięga się po strategie badań jakościowych. Oprócz wspomnianej już strategii studium przypadku, którą Stake wypracował dla potrzeb ewaluacji responsywnej, współcześnie wykorzystuje się etnografię (Nowotniak 2013, 2019) oraz autoetnografię, etnografię wizualną (Nowotniak 2012; Maciejewska 2020), metodę dokumentarną (Krzychała, Zamorska 2008) oraz badania partycypacyjne (Cuprjak 2014).

\section{Przestrzenie dla ewaluacji konstruktywistycznych we wczesnej edukacji}

Poszukując potencjalnych miejsc dla ewaluacji konstruktywistycznych we wczesnej edukacji, warto rozważyć kilka szczegółowych kwestii. Odnoszą się one do pytań o przedmiot, cele i zadania tych ewaluacji, o ich konceptualizację (projektowanie) w warunkach szkoły czy przedszkola, przebieg oraz o komunikowanie wyników.

Mając na uwadze fakt, że analizowane tu ewaluacje są dedykowane badaniu programów, ich przedmiotem mogą być wszelkie projekty i programy realizowane w szkole i w środowisku skierowane do tworzenia warunków uczenia się i rozwoju dziecka. Jako przykłady mogą służyć: programy profilaktyczne, innowacje w zakresie kształcenia, wykorzystanie technologii informatyczno-komunikacyjnych (Bielinis i in. 2018), kształcenie dzieci zdolnych, dwujęzycznych itp. Ogólnie mogą to być wszelkie programy, których adresatami są uczniowie czy nauczyciele. Pamiętać jedynie należy, by nie zacierać różnicy między badaniem naukowym a ewaluacją. Przedmiotem ewaluacji konstruktywistycznych jest opis subiektywnie tworzonych obrazów społecznego świata z perspektywy aksjologicznej. Stąd koncentrujemy uwagę na wartościach przypisywanych doświadczeniu.

W jaki sposób zaprojektować ewaluację konstruktywistyczną w warunkach przedszkola czy szkoły? Niestety, niewiele jest doniesień czy komunikatów z badań opisujących projektowanie ewaluacji konkretnych programów, które mogą stanowić punkt odniesienia. Istniejące teksty odnoszą się przede wszystkim do ewaluacji ilościowych (por. Sylva 1990). Na szczęście powstało wiele opracowań poświęconych metodologii prowadzenia ewaluacji konstruktywistycznych. Jako przykład może służyć książka Helen Simons pt. Case Study Research in Practice (2009).

Projektowanie ewaluacji wymaga dogłębnego przemyślenia każdego etapu badania. Pierwszym z nich jest etap nazywany w literaturze przedmiotu ogniskowaniem ewaluacji 
(Mertens 2010: 69). Określenie przedmiotu oraz zadań ewaluacji, sformułowanie kluczowych pytań oraz dobór kryteriów pozwalają na jej zogniskowanie na kwestiach, które są rzeczywiście ważne. Należy pamiętać, że w ewaluacjach konstruktywistycznych nie istnieje lista gotowych kryteriów, które można wykorzystać w badaniu. Maniera sięgania po kryteria używane w ewaluacjach neoliberalnych (np. po użyteczność, efektywność czy przydatność) świadczy o braku rozumienia ich istoty. Źródłem kryteriów w ewaluacjach konstruktywistycznych są wiedza pedagogiczna oraz teorie określające logikę programu.

Konieczne jest również uspołecznienie procesu tworzenia kryteriów. W ewaluacji responsywnej oznacza to konsultowanie kryteriów z zamawiającymi oraz adresatami programu; w ewaluacji dialogicznej - włączanie bezpośrednich (np. uczniowie) i pośrednich (np. nauczyciele) adresatów w proces projektowania ewaluacji, w tym szczególnie w ustalanie jej kryteriów.

Na etapie projektowania trzeba również podjąć decyzję o wyborze modelu ewaluacji. Spośród wielu modeli, o których wspominałem, we wczesnej edukacji można wykorzystać ewaluacje responsywne oraz dialogiczne. Wybór jest pochodną decyzji o przedmiocie oraz zadaniach, jakie przed sobą stawiamy.

Bardzo ważny jest również etap prowadzący do zdefiniowania listy podmiotów zainteresowanych ewaluacją (stakeholders). W każdym przypadku jest ona inna w zależności od rodzaju i typu ewaluacji. W ewaluacjach konstruktywistycznych należy unikać neoliberalnej, podszytej pychą nowomowy określającej te podmioty mianem „beneficjenci” lub ,interesariusze”.

Kolejną kwestią w procesie konceptualizacji ewaluacji jest wybór strategii badawczej. Można tutaj wykorzystać studium przypadku (case study) - szczególnie w ewaluacjach responsywnych. W ewaluacjach dialogicznych użyteczne mogą się okazać możliwości, jakie tworzą badania etnograficzne, w tym szczególnie etnografia wizualna, etnograficzne studium przypadku (Simons 2009; Mizerek 2017c), metoda dokumentarna (Krzychała, Zamorska 2008), badania partycypacyjne (Reich i in. 2017) czy cieszący się współcześnie dużym zainteresowaniem pedagogów nurt znany jako art-based research (Barone, Eisner 1995; Bagnoli 2009; Binder 2018).

Wybór metod badawczych to kwestia, której w praktyce poświęca się wiele uwagi. Warto wskazać w tym miejscu na metody zbierania danych w wypadku projektów badawczych prowadzonych z dziećmi. Mamy tutaj do wyboru „,klasyczne” metody, np. zogniskowany wywiad grupowy (Maciejewska, Matuszewska 2013), metody z obszaru etnografii wizualnej, m.in. fotoeseje (Nowotniak 2012), photovoice (Darbyshire i in. 2005; Ciolan, Manasia 2017; Woodgate i in. 2017), mapping i podobne metody, w których zachęca się dzieci do wizualizacji własnych doświadczeń w postaci wytworów łączących grafikę i tekst (Keats 2009; Chen 2018). Można też sięgnąć po analizę artefaktów, np. po ślady aktywności dzieci w mediach społecznościowych, wykorzystując metody netnografii (Costello i in. 2017).

Komunikowanie wyników ewaluacji konstruktywistycznych, w tym szczególnie dialogicznej, nie może się ograniczać do pisemnego raportu. Aby osiągnąć cele ewaluacji, ko- 
nieczne jest zapewnienie uczestnictwa w tym procesie możliwie dużej grupy podmiotów, zwłaszcza dzieci. Dzieci nie mogą być jedynie biernymi odbiorcami wniosków z badania. Dobrze byłoby, gdyby mogły zaprezentować doświadczenia zgromadzone w trakcie realizacji programu własnym głosem, sięgając po środki wyrazu bliskie dzieciom. Przykładem może być wykorzystanie dramy oraz prezentacja scenek ilustrujących wnioski z ewaluacji. Można też, inspirując się postulatami art-based research, zachęcać dzieci do przygotowania np. filmu, wiersza lub innych form artystycznego wyrazu (por. Binder 2018). W ten sposób głos dzieci staje się bardziej autentyczny i zrozumiały niż w wypadku pisemnych lub ustnych relacji przekazywanych z intencją uspokojenia sumień realizatorów projektów edukacyjnych oraz tych, którzy takie projekty sponsorują.

Warto na koniec pokreślić, że prowadzenie ewaluacji z udziałem małych dzieci rodzi wiele dylematów etycznych. O niektórych z nich wspominałem. Pojawiają się one na każdym z etapów jej projektowania i prowadzenia. „Przede wszystkim nie szkodzić” - to maksyma, którą należy się kierować. Stając wobec dylematu: dotrzeć do „prawdy” czy chronić dobra osobiste, trzeba zawsze wybrać to drugie.

\section{Uwagi końcowe}

Ewaluacje konstruktywistyczne mają ugruntowaną pozycję w teorii i praktyce ewaluacji. Zapoczątkowane na początku lat 70. ubiegłego stulecia przez Roberta Stake'a, na przełomie wieków stały się wiodącym nurtem - szczególnie w ewaluacji edukacyjnej. Dzieje się tak do dzisiaj, mimo że obecnie mamy do czynienia z rosnącymi wpływami modeli ewaluacji powstałymi w ramach „renesansu” (lub recydywy) neopozytywizmu. Używając języka Everta Vedunga (2010) - ewaluacje konstruktywistyczne zostały zalane przez falę ewaluacji neoliberalnych i tych podporządkowanych ideologii „złotego standardu”. Edukacja stara się przed tym bronić, niestety niezbyt skutecznie. Najlepszym tego przykładem jest wykorzystywanie „ewaluacji” w szkolnictwie wyższym do celów parametryzacji.

Oczywista jest szkodliwość tego typu ideologii dla edukacji. Promują one dyskurs zmiany w edukacji, który ignoruje jej istotę. Klasyczne wartości, jakimi są prawda, dobro i piękno, zostały zredukowane do nowej neoliberalnej triady - rynek, klient i usługa. Dyskurs jakości edukacji został podporządkowany satysfakcji klienta oraz ekonomicznej efektywności. Obraz dobrej szkoły ma być budowany na podstawie wyników zewnętrznego testowania osiągnięć uczniów. Przykłady można mnożyć.

Trzeba przyznać rację Dorocie Klus-Stańskiej, że diagnoza i ewaluacja „,podlane neoliberalnym sosem” nie dają szans na „zmianę logiki tworzącej edukację” (2013: 87). Taką szansę tworzą jednak nadal ewaluacje konstruktywistyczne. Sądzę, że wczesna edukacja jest dobrym obszarem do wykorzystania możliwości, jakie tworzą dobrze przemyślane i przeprowadzone odmiany ewaluacji konstruktywistycznych. 


\section{Literatura}

Bagnoli A. (2009), Beyond the standard interview: the use of graphic elicitation and arts-based methods QR. „Qualitative Research”, 9(5).

Barone T., Eisner E.W. (1995), Arts-Based Educational Research. W: T. Barone, E.W. Eisner (eds.), Arts-Based Research. London, Thousand Oaks, New Delhi, SAGE Publications.

Bielinis L., Kurkowski C., Maciejewska M. (2018), „Tubylec tubylcowi nierówny”. Przyszli nauczyciele o uczeniu się w epoce cyfrowej. „Problemy Wczesnej Edukacji”, 41(2).

Binder M.J. (2018), Bringing the arts to the everyday lived experiences of young children. „Art/ Research International: A Transdisciplinary Journal", 3(2).

Chelimsky E. (1997), Thoughts for a New Evaluation Society. „Evaluation”, 3(1).

Chen A.T. (2018), Timeline Drawing and the Online Scrapbook: Two Visual Elicitation Techniques for a Richer Exploration of Illness Journeys. „International Journal of Qualitative Methods", 17(1).

Ciolan L., Manasia L. (2017), Reframing Photovoice to Boost Its Potential for Learning Research. „International Journal of Qualitative Methods”, 16.

Costello L., McDermott M.-L., Wallace R. (2017), Netnography: Range of Practices, Misperceptions, and Missed Opportunities. „International Journal of Qualitative Methods”, 16.

Cousins J.B., Earl L.M. (1992), The Case for Participatory Evaluation. „Educational Evaluation and Policy Analysis", 14(4).

Cuprjak M. (2014), Doświadczanie codzienności ucznia. Etnografia zaangażowana. „Przegląd Badań Edukacyjnych", 18(1).

Darbyshire P., MacDougall C., Schiller W. (2005), Multiple methods in qualitative research with children: more insight or just more? „Qualitative Research”, 5(4).

Fettermann D.D., Wandersman A. (2007), Empowerment Evaluation: Yesterday, Today, and Tomorrow. „American Journal of Evaluation”, 28(2).

Gołębniak D.B., Zamorska B. (2014), Nowy profesjonalizm nauczycieli. Podejścia - praktyka przestrzeń rozwoju. Wrocław, Wydawnictwo Naukowe Dolnośląskiej Szkoły Wyższej.

Greene J.C. (2001), A Relational Perspective. „Evaluation”, 7(2).

Groewald M. (2013), Sens spotkań diagnostyki z ewaluacja w szkole. „Teraźniejszość - Człowiek Edukacja", 4(64).

Grzesiak J. (2008), Ewaluacja w dialogu wobec badań jakościowych w edukacji. W: J. Grzesiak (red.), Ewaluacja i innowacje w edukacji. Dialog w ewaluacji-ewaluacja w dialogu. KaliszKonin, PWSZ.

Guba E., Lincoln Y. (1989), Fourth Generation Evaluation. London, Thousand Oaks, New Delhi, SAGE Publications, Inc.

Hall J.N., Ahn J., Greene J.C. (2012), Values engagement in evaluation: Ideas, illustrations, and implications. „American Journal of Evaluation”, 33(2).

House E., Howe K. (2000), Deliberative democratic evaluation. W: L. DeStefano, K. Ryan (eds.), Evaluation as a democratic process: Promoting inclusion dialogue, and deliberation. San Francisco, Jossey-Bass.

Howe K.R., Ashcraft C. (2005), Deliberative democratic evaluation: Successes and limitations of an evaluation of school choice. „Teachers College Record”, 107(10). 
Jaskuła S. (2012), Ewaluacja rozwojowa jako wyzwanie współczesnego systemu edukacji. „Zarządzanie Publiczne", 3(19).

Jaskuła S. (2013), Pedagogika ewaluacji. „Teraźniejszość - Człowiek - Edukacja”, 4(64).

Jaskuła S. (2018), Ewaluacja społeczna w edukacji. Kraków, Oficyna Wydawnicza „Impuls”.

Jaskuła S., Korporowicz L. (2014), Odrębność i współgranie. Polskie relacje diagnostyki i ewaluacji edukacyjnej. „Ruch Pedagogiczny”, 2.

Keats P. (2009), Multiple text analysis in narrative research: visual, written, and spoken stories of experience. „Qualitative Research”, 9(2).

Klus-Stańska D. (2013), Myślenie poza diagnoza i ewaluacją. Pytanie o możliwość zmiany logiki tworzacej edukację. „Teraźniejszość - Człowiek - Edukacja”, 4(64).

Konecki K. (2000), Studia z metodologii badań jakościowych. Teoria ugruntowana. Warszawa, Wydawnictwo Naukowe PWN.

Korporowicz L. (2011), Zmienne losy polskiej ewaluacji. Pomiędzy nadzieja, animacja i konfuzja. W: B. Niemierko, K. Szmigiel (red.), Ewaluacja w edukacji. Koncepcje. Metody. Perspektywy. Kraków, Grupa Tomani.

Korporowicz L. (2013), Społeczna etyka ewaluacji. „Teraźniejszość - Człowiek - Edukacja”, 4(64).

Krzychała S., Zamorska B. (2008), Dokumentarna ewaluacja szkolnej codzienności. Wrocław, Wydawnictwo Naukowe Dolnośląskiej Szkoły Wyższej.

Kwaśnica R. (2014), Dyskurs edukacyjny po inwazji rozumu instrumentalnego. O potrzebie refleksyjności. Wrocław, Wydawnictwo Naukowe Dolnośląskiej Szkoły Wyższej.

Lincoln Y.S. (2009), Ethical practices in qualitative research. W: D.M. Mertens, P. Ginsberg (eds.), The Handbook of Social Research Ethics. Thousand Oaks, California, SAGE Publications, Inc.

Maciejewska M. (2018), Badania ewaluacyjne w edukacji jako źródto wiedzy pedagogicznej. „Forum Pedagogiczne", 8(2).

Maciejewska M. (2020), Wykorzystanie etnografii wizualnej w procesie rozpoznawania problemów spolecznych przez studentów. „Forum Pedagogiczne”, 10(2).

Maciejewska M., Matuszewska A. (2013), Jak uprawiać badania ewaluacyjne w edukacji? Możliwości wykorzystania zogniskowanych wywiadów grupowych (FGI) w ewaluacji jakościowej. W: H. Kędzierska, H. Mizerek (red.), Jakościowe inspiracje w badaniach edukacyjnych - refleksje na marginesie projektów badawczych. Olsztyn, Wydawnictwo Uniwersytetu Warmińsko-Mazurskiego.

Mehrizi M.H.R., Ghasemzadeh F., Molas-Gallart J. (2009), Stakeholder Mapping as an Assessment Framework for Policy Implementation. „Evaluation”, 15(4).

Mertens D.M. (1999), Inclusive evaluation: implications of transformative theory for evaluation. „American Journal of Evaluation”, 20(1).

Mertens D.M. (2003), The inclusive view of evaluation: Vision for the new millenium. W: S.I. Donaldson, M. Scriven (eds.), Evaluating social programs and problems. Visions for the new millennium. London-New York, SAGE Publications, Inc.

Mertens D.M. (2010), Research and Evaluation in Education and Psychology. Los Ageles, London, New Dehli, Singapore, Washington DC, SAGE Publications, Inc.

Mizerek H. (2017a), Badania ewaluacyjne w edukacji-lekcje do odrobienia. W: D. Kubinowski, M. Chutorański (red.), Pedagogika jako humanistyczno-społeczna nauka stosowana: konsekwencje metodologiczne. Kraków, Oficyna Wydawnicza „Impuls”.

Mizerek H. (2017b), Ewaluacja edukacyjna. Interdyskursywne dialogi i konfrontacje. Kraków, Oficyna Wydawnicza „Impuls”. 
Mizerek H. (2017c), Studium przypadku w badaniach nad edukacja. Istota i paleta zastosowań. „Przegląd Pedagogiczny”, 1.

Mizerek H. (2018), Ewaluacja edukacyjna w obliczu pytań o teraźniejszość i zmianę. szkic do portretu szans niewykorzystanych. „Forum Oświatowe”, 30(1).

Niemierko B. (2013), Czy diagnostyka edukacyjna i ewaluacja w edukacji zachowają odrębność? „Teraźniejszość - Człowiek - Edukacja”, 4(64).

Nowotniak J. (2012), Etnografia wizualna w badaniach i praktyce pedagogicznej. Kraków, Oficyna Wydawnicza „Impuls”.

Nowotniak J. (2013), Badania etnograficzne z elementami wizualnymi w kształceniu akademickim możliwości i ograniczenia. „Opuscula Sociologica”, (4).

Nowotniak J. (2017), Miejsce, swoistość, metodologiczna różnorodność badań ewaluacyjnych w pedagogice - konsekwencje dla pedagogiki. W: D. Kubinowski, M. Chutorański (red.), Pedagogika jako humanistyczno-społeczna nauka stosowana. Konsekwencje metodologiczne. Kraków, Oficyna Wydawnicza „Impuls”.

Nowotniak J. (2019), Ewaluacja edukacyjna. Społeczne światy ewaluatorów. Kraków, Oficyna Wydawnicza „Impuls”.

Potulicka E. (2014), Neoliberalne reformy edukacji w Stanach Zjednoczonych. Od Ronalda Reagana do Baracka Obamy. Kraków, Oficyna Wydawnicza „Impuls”.

Potulicka E., Rutkowiak J. (2010), Neoliberalne uwikłania edukacji. Kraków, Oficyna Wydawnicza „Impuls”.

Reich J., Liebenberg L., Denny M., Battiste H., Bernard A., Christmas K., Paul H. (2017), In this together: Relational accountability and meaningful research and dissemination with youth. „International Journal of Qualitative Methods", 16.

Rutkowiak J. (2012), Jak kształtować kulturę zaufania i odpowiedzialności w szkole w warunkach promowania rywalizacji przez neoliberalizm? „Studia Edukacyjne”, 22.

Simons H. (2009), Case Study Research in Practice. London-New York, SAGE Publications, Inc.

Stake R. (1995), The Art af Case Study Research. Thousand Oaks, London, New Dehli, SAGE Publications, Inc.

Stake R. (2003), Responsive Evaluation. W: T. Kellaghan, D.L. Stufflebeam (eds.), International Handbook of Educational Evaluation. Dordrecht, Springer.

Stake R., Abma T.A. (2005), Responsive evaluation. W: S. Mathison (ed.), Encyclopedia of Evaluation. Thousand Oaks, SAGE Publications, Ltd.

Stufflebeam D.L. (2001), Evaluation Models. „New Directions for Evaluation”, 89.

Sylva K. (1990), Evaluating early education programmes. „Early Child Development and Care”, $58(1)$.

Szyling G. (2013), Diagnoza i ewaluacja a teoretyczne horyzonty refleksji nad działaniem. „Teraźniejszość - Człowiek - Edukacja”, 4(64).

Tapella E., Rodríguez-Bilella P. (2014), Shared learning and participatory evaluation: The sistematización approach to assess development interventions. „Evaluation”, 20(1).

Vedung E. (2010), Four Waves of Evaluation Diffusion. „Evaluation”, 16(3).

Woodgate R.L., Zurba M., Tennent P. (2017), Worth a Thousand Words? Advantages, Challenges and Opportunities in Working with Photovoice as a Qualitative Research Method with Youth and their Families. „Forum: Qualitative Social Research”, 18(1). 